\title{
The Juku Online Writing System as an Interactive College English Writing Instructional Tool in China
}

\author{
Liu, Dianping'; Kim, Yang-Hee ${ }^{2}$
}

\begin{abstract}
The purpose of this study is to investigate the effects of the Juku online writing system as an interactive writing tool. A process-genre approach was implemented with this tool to cultivate college students' English writing ability, one of the key competences in English currently promoted in China. Seventy-seven non-English major undergraduates at a comprehensive four-year university in Jilin Province were surveyed on their writing experiences in English class during a period of 12 weeks of writing practice. Descriptive statistics and $t$-tests by means of SPSS were used to analyze both surveys by students of their writing experiences as well as the effects of the Juku approach, and students' improvement in essay writing. The results showed that compared with a traditional product-based writing instruction approach, the Juku system's diversified evaluation, and interactive teaching instruction aroused students' enthusiasm for learning and self-confidence in writing and helped students develop good writing habits as well. Moreover, analysis of students' writing performance showed significant improvements in students' writing scores from the pre-test to the post-test. Students' improvements with respect to lexical variables, syntactic variables and discourse variables were also indicated. Based on these findings, educational implications for the promotion of writing instruction are presented at the end of the paper.
\end{abstract}

Keywords: Juku online writing system, interactive writing tool, English writing ability, process-genre approach, key competences in English

Applicable levels: secondary, tertiary

\footnotetext{
* This work was supported by a General Grant on Higher Education and Teaching Reform of the NEAC, China (19080); a General Grant of Jilin Higher Education Institution (JGJX2019D39); a General Grant of Jilin Occupational and Adult Education and Teaching Reform (2018ZCY235); a General Grant of Social Science Fund of Jilin Province, China (2021B225)

${ }^{1}$ First author, Professor, College of Foreign Languages, Yanbian University, 977, Gongyuan Road, Yanji City, Jilin Province, 133002, China (E-mail: liudianping@ybu.edu.cn)

${ }^{2}$ Corresponding author, Professor, Dept. of English Language and Literature, Baekseok University, 1, Baekseokdaehak-ro, Dongnam-gu, Cheonan-si, Chungcheongnam-do, 31065, Korea (E-mail: 214julie@bu.ac.kr)
}

Received: April 15, 2021

Revised: May 15, 2021

Accepted: May 23, 2021
Copyright: (C) 2021 The Society for Teaching English through Media (STEM)

This is an open access article distributed under the terms of the Creative Commons Attribution Non-Commercial License (http://creativecommons.org/licenses/by-nc/4.0), which permits unrestricted non-commercial use, distribution, and reproduction in any medium, provided the original work is properly cited. 


\section{INTRODUCTION}

In China, the College English Teaching Guidelines (2020) emphasizes the importance of promoting students' allaround development while cultivating their ability to use English comprehensively in listening, speaking, reading, writing, and translating. This curricular orientation coincides with the fundamental educational goal of "cultivating students' key competences" with respect to knowledge, skills, emotions, attitudes, values and so on (General English Curriculum Standards in China, 2017). The cultivation of students' key competences is expected to be integrated into every subject, including English.

However, the actual instruction of college English, especially the focus on the study of written practice, is not key competence oriented but knowledge teacher oriented. Due to the influence of this fixed traditional conception of English teaching, English instruction is still regarded more as a process of accumulating knowledge (i.e., input) rather than as a process of expression (i.e., output). Furthermore, cultivating students' writing ability is regarded as hardest and most time-consuming among the four basic language abilities targeted in English instruction (Gu \& Wang, 2012; Shi, 2015; Zhang, 2009). It is even more challenging to cultivate students' writing ability in the less developed educational contexts of ethnic minority areas, where students' weak English foundations, ethnic differences, limited instructional time, and big class sizes create more obstacles to English writing practice.

To save time during tight teaching schedules, Chinese instructors of English mainly choose to follow the traditional product-based writing approach. This approach focuses on English knowledge and regards writing as a mechanical imitation activity. This product-based approach also ignores the cultivation of students' key competences in English as well as emotional contributors to learning such as student interest, self-confidence and involvement, which leads to difficulty in promoting good writing habits as well as students' actual writing ability (Yu \& Zhang, 1996). Lee (2010) indicates that pedagogical methods such as the product-based approach inhibit learners' creativity and engagement as well. Students exposed to this approach become passive learners who tend to follow model writing procedures mechanically, thereby suppressing their intrinsic interest, enthusiasm and creativity (Xu, 2012; Yang, 2015).

In order to improve the effectiveness of English writing instruction, researchers and practitioners have begun to explore pedagogical reforms. Some studies indicate that incorporating the process-genre approach into traditional English writing instruction can yield both affective and linguistic advantages, such as promoting students' emotional engagement as well as their writing ability (Badger \& White, 2000; Shi, 2015; Wang, 2019; Zhang, 2013). The process-genre approach can benefit further from online evaluation systems, which include automatic writing evaluation and can increase student-instructor interaction as well as student engagement in writing tasks. However, few studies have examined the effects of online evaluation systems, particularly in the context of comparisons between traditional product-based writing approaches and online interactive writing approaches. In light of this gap in prior research, the present study examined the effects of the Juku automatic writing evaluation system ${ }^{1}$. As one of many online evaluation systems, this interactive writing tool can be readily integrated with a process-genre instructional approach to cultivating college students' writing ability within the framework of key competences in English. This study examined the impact of the Juku system on key competences in English writing among college students in an ethnic minority area of China.

\section{LITERATURE REVIEW}

\section{English Instruction Reform in China}

Recently China has begun national educational reform that focuses on development of key competences in all subjects, owing in part to the influence of educational reform in the EU and other countries (Liu, 2018). Key

\footnotetext{
${ }^{1}$ The Juku automatic writing evaluation system (JAWES, http://www.pigai.org) is one of the commonly used systems of writing instruction among colleges and universities in China. It was developed domestically and provides automatic online correction services and real time scoring and diagnostic feedback in the form of SAAS (Software as a Service) based on a corpus and cloud computing platform.
} 
competences in English are defined as crucial competences that students should acquire during English education at different levels, including language competence, cultural competence, learning competence, and thinking competence (Cheng \& Zhao, 2016; General English Curriculum Standards in China, 2017). Competence-based reform assumes that key competences in language include not only basic knowledge such as vocabulary and grammar, but also the capacity to understand and express meanings, emotions, and attitudes, to engage in critical analysis, and to otherwise participate in meaningful communication (Cheng \& Zhao, 2016). English teachers as instructors and researchers who offer guidance on students' learning, are expected to encourage students to be active, independent, explicit and creative with respect to learning English. How these competences are fostered by English instruction will be crucial to translating national educational reform into local practice and to bridging the gap between China's long-term educational goals and current educational practice (Liu, 2019).

\section{The Methods to Teach Writing}

Traditional college English instruction, especially writing instruction, is still exam-oriented in rural areas of China. Local educational practice must meet students' need to perform well on English exams like the College English Test Band 4 and 6 (CET $4 \&$ 6), to ensure that students can graduate and gain advantage in the competitive employment market. Thus, students hope that English instruction is exam-focused. At the same time, for much the same reasons, instructors provide knowledge-oriented and exam-focused instruction (Liu, 2019). Another limitation in English instruction is that it is mainly teacher-centered and there is not sufficient interaction among teachers and students, or among students themselves, with respect to writing-related tasks. Instructors ignore the roles that students can play in different aspects of writing instruction. More research on how interactions during writing instruction can improve students' writing performance is needed (Cai, 2009).

In ethnic minority areas of China, students' relatively weak English foundations, ethnic differences, limited instructional time, and large classes make it harder for competence-oriented instruction to be implemented. In some colleges, writing instruction is overlooked or given up due to instructors' stereotyped views of students' writing ability, as instructors regard it as the most difficult ability to improve compared to other basic language abilities like listening, speaking and reading (Gu \& Wang, 2012; Shi, 2015; Zhang, 2009). Most instructors follow the traditional product-based writing approach and focus on knowledge accumulation, thereby saving time for their tight teaching schedules, even though they are cognizant of this approach's disadvantages.

The focus of the product-based writing approach is mainly on sentence-level structural linguistics and bottom-up processing knowledge acquisition. It regards imitation as the best way to learn writing, ignoring the cultivation of writing skills such as writing plans and good writing habits. This approach may discourage students to recognize to whom and why they write and how to create and formulate their own ideas during the writing process, since it ignores students' inherent knowledge and skills (Han, 2001; Kim, 2016; Shi, 2015; Zhang, 2013). However, the frustrating reality is that students' writing ability will not improve without positive engagement, even though instructors put much time into their instruction. How to nurture emotional contributors to learning, to arouse students' enthusiasm for writing, and to improve their positive engagement in the writing process become the challenges that English instructors have to face. Lastly, the evaluation on writing provided by instructors is time-consuming to generate, ineffective and inefficient. Instructors either take too much time to give students feedback and guidance on their writing or fail to give students any feedback and further evaluation except for the allocation of a grade.

The process-genre approach, proposed by Richard Badger and Goodith White of the United Kingdom in 2000, offers a new way of improving English writing instruction. The process-genre approach is based on constructivist theory, interaction theory, cooperative learning theory and genre theory. It assumes that the three main approaches to writing instruction (product, process, and genre approaches) are complementary, and that ultimately the best approach represents a combination informed by each of them (Badger \& White, 2000). Many studies have shown that the process-genre approach is a more effective instructional approach to improving students' writing ability and has a positive effect on affective variables such as interest, self-confidence and engagement (Cai, 2009; Shi, 2015; Wang, 2019; Zhang, 2009, 2013). Furthermore, some studies conclude that this approach promotes good writing habits (Wu, 2005; Yang, 2002; Yao, 2010).

However, what prior studies overlook is that compared to traditional writing approaches, the process-genre 
approach is also time-consuming, especially with respect to feedback and writing evaluation, since it emphasizes repeated modification and revision. Studies on how to improve the efficiency of the process-genre approach are crucial, especially in college English instruction where instructional time is limited. With the development of internetbased educational technology, many universities in China have started promoting the use of an online intelligent correction system called the Juku online writing evaluation system. The Juku provides automatic online correction services for teachers and English learners in the form of SAAS (Software as a Service), and provides real time scoring as well as diagnostic feedback. The advantages of the Juku lie in its stimulation of students to modify their writing actively through constant feedback based on corpus analysis, as well as its interactive "student-centered" design, which makes writing a multi-way activity in which teachers, students and the evaluation system can participate and cooperate with each other. It is hoped that the increased interactiveness enabled by the Juku system can break the traditional tendency to focus narrowly on the instrumental function of language and promote learning competences including emotional contributors to learning such as enthusiasm and self-confidence ( $\mathrm{Gu} \&$ Wang, 2012). Furthermore, the Juku can release instructors from some of their time-consuming grading and evaluation as well (Jiao \& Yuan, 2016).

Although the Juku system can conduct automatic and timely evaluation, in practice most instructors simply use it as a platform to assign writing tasks, relying on its high efficiency for giving automatic feedback on students' writing, thereby reducing the amount of individual evaluation and feedback they provide. Research is lacking as to whether feedback itself can improve students' writing ability, engagement in writing, good writing habits, and so on, without instructors' guidance, or whether interactions between instructors and students, and among students themselves, are also needed. Another limitation of prior research is lack of attention to the improvement of traditional writing approaches by incorporating the Juku system as an interactive writing tool and process-genre approach, with the goal of improving key competences in English. In light of these considerations, the following research questions were addressed in this study:

1. What are students' views and satisfaction with traditional English writing instruction?

2. Compared with the traditional approach to writing instruction, what are the effects of an interactive writing instructional approach that incorporates the Juku online writing system?

\section{METHOD}

\section{Participants}

The study was conducted in Jilin province, China. Convenience sampling and purposive sampling were used to ensure the representativeness of participants. These participants included 77 non-English major sophomore college students from two sections of a compulsory college English course at a comprehensive four-year university, located in Yanbian Korean Autonomous Prefecture. The same instructor taught each section, in order to ensure the same teaching style in this study. Of the 77 student participants, $36 \%$ were male, and $64 \%$ were female. $60 \%$ were Han Chinese, and $40 \%$ were Korean Chinese or another ethnic minority.

In this study, we evaluated English writing abilities in terms of students' pass rate on the CET 4, the most commonly used national test in China to determine non-major English college students' English proficiency. Preliminary analyses showed that students' pass rate on the CET 4 was only $34 \%$ and unrelated to ethnicity. In the writing and translation part of this test, the pass rate of the participants was only $21 \%$, reflecting students' overall weak writing ability.

In response to survey items concerning students' attitudes toward English writing, $45 \%$ of the students somewhat or mostly agreed with the statement that they were interested in writing, while $55 \%$ of them indicated that they were uncertain, or that they somewhat or mostly disagreed with the statement. Similarly, $59 \%$ of the students somewhat or mostly agreed that they were self-confident in writing, $41 \%$ of them were either uncertain, or somewhat or mostly disagreed with that statement. These preliminary analyses suggest that students not only had a low pass rate on the CET 4 but were also not very interested or self-confident with respect to writing. 
Students' views on difficulties they confronted in writing and their writing habits are shown in Table 1 and Table 2. Language expressions were cited as the main cause of writing difficulties, perhaps reflecting instructors' neglect of training students' writing in specific genres. In addition, the majority of the students did not report good writing habits like making drafts or outlines, revising what they wrote during writing or after evaluation. Instructors' evaluations did not help improve students' effective writing habits because all evaluations were just given once, and no further revision or evaluation was conducted.

TABLE 1

Participants' Writing Difficulties (Questions 1-4)

\begin{tabular}{|c|c|c|}
\hline Question & Response Option & Percentage $(N=77)$ \\
\hline \multirow{4}{*}{$\begin{array}{l}\text { 1. What is the weakest part of } \\
\text { your writing? }\end{array}$} & A. Language expressions & A. $70 \%$ \\
\hline & B. Logicality and coherence & B. $16 \%$ \\
\hline & C. Layouts & C. $8 \%$ \\
\hline & D. Ideological contents & D. $6 \%$ \\
\hline \multirow{3}{*}{$\begin{array}{l}\text { 2. What are the most common } \\
\text { errors you make? }\end{array}$} & A. Syntactic errors & A. $53 \%$ \\
\hline & B. Lexical errors & B. $42 \%$ \\
\hline & C. Coherence among paragraphs & C. $5 \%$ \\
\hline \multirow{3}{*}{$\begin{array}{l}\text { 3. What is the main reason for } \\
\text { your errors? }\end{array}$} & A. Lack of vocabulary & A. $45 \%$ \\
\hline & B. Lack of grammatical knowledge & B. $40 \%$ \\
\hline & C. Negative effect of mother tongue & C. $15 \%$ \\
\hline \multirow{4}{*}{$\begin{array}{l}\text { 4. What is the main reason for } \\
\text { your overall weak writing } \\
\text { ability? }\end{array}$} & A. Lack of knowledge about specific genres & A. $34 \%$ \\
\hline & B. Lack of knowledge about writing skills & B. $32 \%$ \\
\hline & C. Weak English expression ability & C. $22 \%$ \\
\hline & D. Thinking differences between English and my mother tongue & D. $12 \%$ \\
\hline
\end{tabular}

TABLE 2

Participants' Writing Habits (Question 5-7)

\begin{tabular}{lcccc}
\hline \multicolumn{1}{c}{ Response Option } & \multicolumn{3}{c}{ Percentage $(N=77)$} \\
\hline \multicolumn{1}{c}{ Question } & $\mathrm{A}$ & $\mathrm{B}$ & $\mathrm{C}$ & $\mathrm{D}$ \\
\hline 5. I made outlines or drafts during writing. & $18 \%$ & $22 \%$ & $18 \%$ & $15 \%$ \\
6. I checked my essays during writing. & $18 \%$ & $36 \%$ & $6 \%$ & $22 \%$ \\
7. I revised my essays after evaluation. & $20 \%$ & $22 \%$ & $17 \%$ & $21 \%$ \\
\hline
\end{tabular}

Note. $\mathrm{A}=$ Mostly agree $\mathrm{B}=$ Somewhat agree $\mathrm{C}=$ Uncertain $\mathrm{D}=$ Somewhat disagree $\mathrm{E}=$ Mostly disagree

\section{Procedures}

In this study, the researcher creatively implemented an interactive Juku online writing system with a process-genre approach so as to make full use of the opportunities available through this multimedia network technology to improve the whole writing instruction process.

During the 12 weeks of writing instruction in each of the two sections, four essay-writing tasks were assigned to students. The instruction followed a pattern combining the process-genre approach with multiple, interactive evaluations from the Juku online system, as well as evaluation by instructors and peers. Students were required to write four essays step by step, as shown in Figure 1. First, before assigning each essay-writing task, the instructor made use of the reading article in class as a sample to give students sufficient input on writing strategies with respect to ideological content, layout, logical coherence, and language expression. After that, students started imitative writing and finished the first draft of their paper, followed by face-to-face interactive peer and teacher evaluations that focused mainly on ideological content, layout, and logical coherence. After the first draft revision, students wrote their second draft for the Juku online writing evaluation system. The interaction between the instructor and students, between students and students, between the Juku system and the students would continue both online and personally until students' final essay sharing (see Figure 1). 
FIGURE 1

Interactive Writing Approach

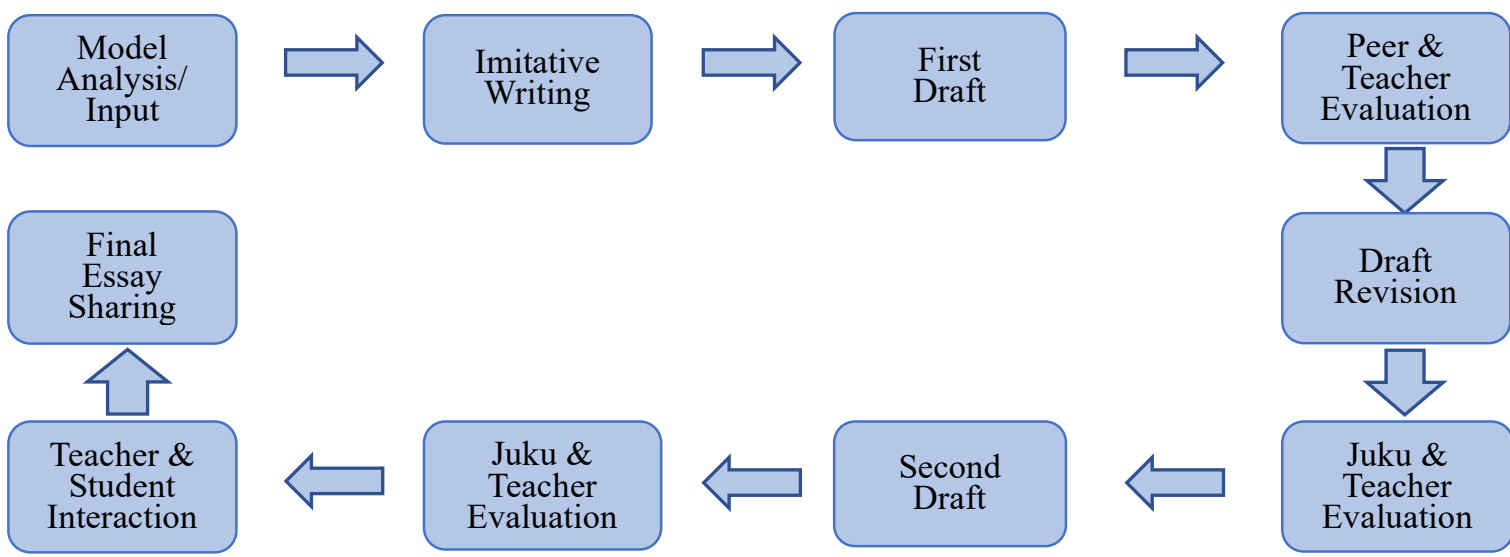

(Badger \& White, 2000; Han, 2001; Li, 2015)

The Juku system offered students the opportunity to revise and submit their writing repeatedly until they were satisfied with the results. After each submission, the frequency that students revised their essays and the change of their scores and ranks in the whole class would be recorded and then be shown to the students individually and collectively. In this way, it was expected that good writing habits like checking, revising, and learning from their own mistakes were promoted. The data collected and analyzed automatically online could be a reference and ground for the instructor to evaluate students' learning attitudes, writing habits and improvement in the writing process. It could also help the instructor adjust and improve her instruction.

Furthermore, it was expected that students would be more stimulated, more interested and more self-confident after seeing improvement due to their active involvement and seeing their ranks in the whole class. After each submission, students received a timely and detailed evaluation, including an overall score, a brief comment on the essay, and highlighting all the errors they made. Suggestions for revision were given with respect to incorrect capitalization, sentence errors, misspelling, parts-of-speech errors, punctuation etc. Taking subject-predicate consistency as an example, students would see a warning labeling this error type, accompanied by suggestions on how to correct it after clicking the label. Following the cues and suggestions, students would try and explore on their own accordingly. With the system's guidance, the writing process was more like an interactive communication process and a learning journey, in which students' interests and spirit of exploration could be aroused more (see Figure 2).

\section{FIGURE 2}

\section{Grading and Comment Interface}

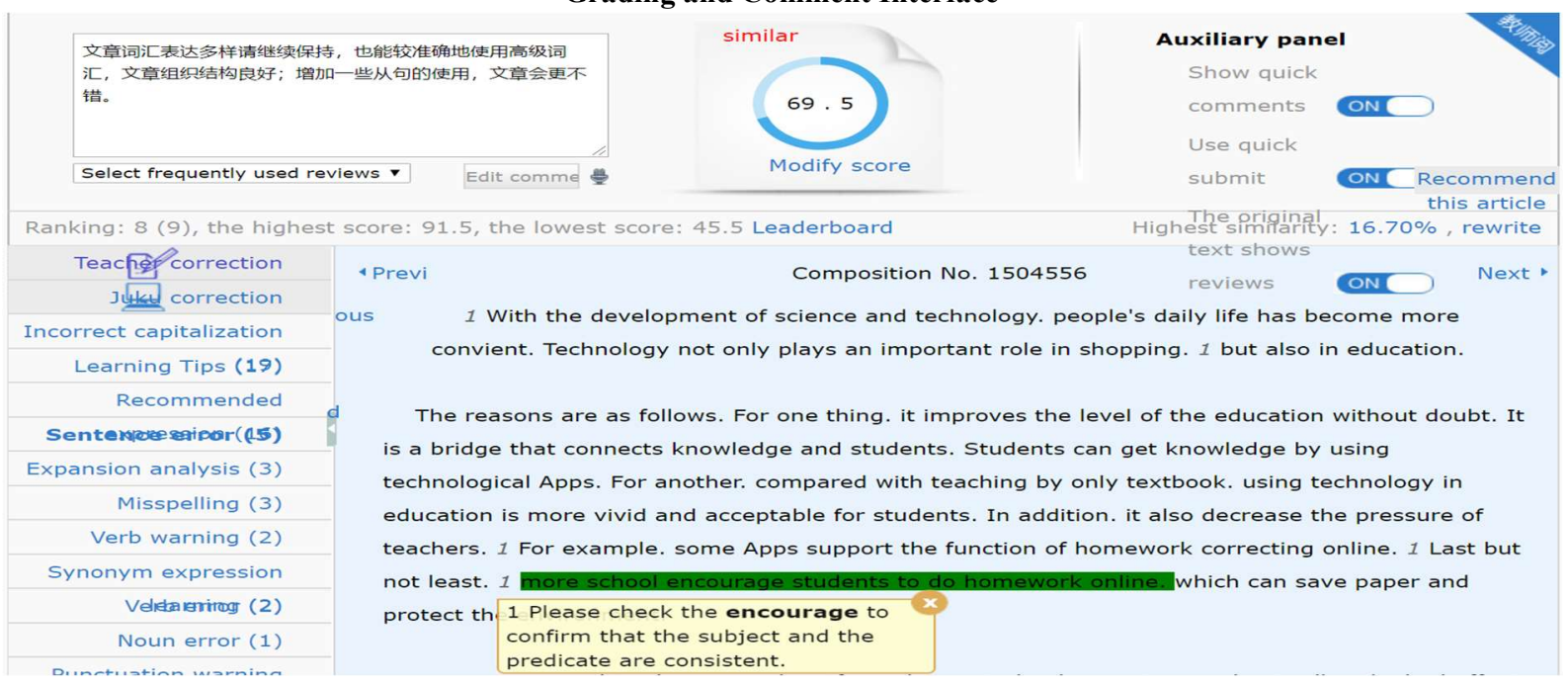


As shown in Figure 3, the Juku system also provided more detailed sentence-by-sentence comments, recommendations, and learning tips. These functions helped promote students' language expressions directly. The instructor and students could also give comments through quick comment and peer evaluation functions in an interactive way if the instructor thought that further comments were needed.

\begin{tabular}{|c|c|c|c|c|}
\hline \multicolumn{5}{|c|}{$\begin{array}{c}\text { FIGURE } 3 \\
\text { Sentence-by-Sentence Comment Interface }\end{array}$} \\
\hline Comment by sentence & comment & recommend & Claim & model essay \\
\hline $\begin{array}{l}1.1 \text { With the development of } \\
\text { Review ] [ } \because \text { 0] }\end{array}$ & nce and techn & ogy. [ & $\begin{array}{l}\text { (1) [Sentence } \\
\Psi \text { [Learning }] \\
\text { technolog }\end{array}$ & $\begin{array}{l}\text { or] Suspected predicate is missing, please check. } \\
\text { ] Confusing vocabulary: technique and } \\
\text { ave the meaning of "technology". }\end{array}$ \\
\hline $\begin{array}{l}1.2 \text { people's daily life has bec } \\
{\left[\begin{array}{ll}{[} & 0\end{array}\right]}\end{array}$ & more convie & [ Review ] & $\begin{array}{l}\text { [Spelling e } \\
\text { options are } \\
\text { [Incorrect } \\
\text { the senten } \\
\text { [Recomme } \\
\text { Individuals } \\
\text { meaning a } \\
\text { [Expanded } \\
\text { daily and }\end{array}$ & $\begin{array}{l}\text { ] The spelling error of convient, the alternative } \\
\text { onvenient, convent, convents, convened. } \\
\text { italization] Please make sure that the first word of } \\
\text { s capitalized. } \\
\text { d expression] } \\
\text { aracters/folks/citizen/the public has the same } \\
\text { oople, and you can refer to it for learning. } \\
\text { alysis] Pay attention to the difference between } \\
\text { mal. }\end{array}$ \\
\hline
\end{tabular}

Note. The original Juku App is written in Chinese; its figures can only be roughly translated into English through an automatic translation tool without correction due to technical reasons. Errors are thus inevitable. Due to practical requirements and video length, Figure 2 and Figure 3 are depicted solely by original screenshots.

The Juku system was able to present, compare and analyze both an individual student's performance and that of the entire class on the same essay-writing task or on different ones (see Appendix 1-3). Validity was guaranteed since all data analysis was based on authoritative corpus data obtained domestically as well as overseas. This analysis could help the instructor adjust and improve her instruction based on students' individual performance and needs as well as those of the class. Students' performance with respect to lexical and syntactic variables could also be compared and analyzed. As for discourse variables not sufficient part of the Juku system, instructor and peer evaluations were provided in order to complement the Juku feedback.

In sum, this process-genre approach was tailor-made for teachers and students and made full use of the Juku online writing system. Furthermore, it offered a window for the instructor to understand students' needs and problems in writing through class-based and online discussions so as to adjust instructional methods accordingly. In this approach to writing instruction, the researcher emphasized the creative use of the Juku system under the instructor' supervision in order to promote a positive view of revision and evaluation among the students. The instructor gave students sufficient information about instruction, on how to make use of the online Juku App to write, and how to revise their papers on their own, as well as in response to evaluative feedback from the instructor and peer. Thus, the instructor ensured that writing instruction incorporated communication between students and teachers, students and students, students and technology, and students and the imaginary readers emphasized in the process-genre approach.

\section{Methods of Analysis}

The survey used in this study was based on scales validated in prior research and modified to fit actual teaching practice at the university where the study was conducted (Gu \& Wang, 2012; Shi, 2015; Xu, 2012). The survey consisted of two parts whose responses were collected by a research assistant. Descriptive statistics and $t$-test analyses were conducted by means of SPSS. 
The first part of the survey explored students' experiences with traditional English writing instruction conducted by other instructors before taking this course. Students' attitudes toward writing, practical difficulties, writing habits, and their views and evaluation of this approach were explored so as to adjust and design new writing instruction accordingly on the basis of both the process-genre approach and students' experiences.

The second part of the survey examined the effects of the Juku online writing system as an interactive writing tool in the context of a process-genre approach to promoting key English competences. Students' satisfaction and experiences with this approach were explored, along with changes in the quality of their essay writing from the beginning to the end of a 12-week period of writing practice. Survey questions were presented in either multiplechoice or Likert-type response format. Likert-scaled questions presented the following response options: mostly agree, somewhat agree, uncertain, somewhat disagree, mostly disagree. Analyses examined whether the Juku system, incorporated into a process-genre approach, cultivated writing abilities more effectively than the traditional teacherproduct-centered one did.

\section{RESULTS}

\section{Students' Views on and Satisfaction With Traditional English Writing Instruction}

In this part, four items concerning students' satisfaction with English writing instruction and three items concerning instructors' writing evaluation were analyzed (see Table $3 \& 4$ ). Regarding students' satisfaction with their English writing instruction, the results suggested that either instructors ignored cultivating students' writing abilities or just followed a traditional knowledge-centered approach to writing. Positive effects on students' writing were not indicated, since only about half of the students gave positive responses to the items, and even fewer claimed they could make use of what they learned. Although both students and instructors seemed to have spent much time trying to improve students' language expressions in writing, the overall outcome was not satisfactory.

The results concerning instructors' writing evaluations indicated more problems with the traditional writing approach, especially with respect to evaluation. The contradiction between what instructors used and what students thought should be used indicated a gap between instructors' opinions and students' expectations. The results for two items concerning the use of the Juku online writing system indicated that this system was mostly used as a one-time marking tool without further comments from instructors. Without instructor supervision or students involvement, this was essentially the same as the traditional evaluation approach, focusing on giving students a final score instead of on how to help them improve their writing.

TABLE 3

Participants' Satisfaction With Traditional Writing Instruction (Question 1-4)

\begin{tabular}{|c|c|c|}
\hline Question & Response Option & Percentage $(N=77)$ \\
\hline \multirow{4}{*}{$\begin{array}{l}\text { 1. What was the writing approach } \\
\text { that the instructor applied? }\end{array}$} & A. Self-learning centered & A. $42 \%$ \\
\hline & B. Sample-explanation centered & B. $38 \%$ \\
\hline & C. Sample-discussion centered & C. $16 \%$ \\
\hline & D. Discussion-centered & D. $4 \%$ \\
\hline \multirow{4}{*}{$\begin{array}{l}\text { 2. How did you access writing } \\
\text { materials? }\end{array}$} & A. Surfing the internet & A. $42 \%$ \\
\hline & B. My own personal knowledge & B. $38 \%$ \\
\hline & C. Through instruction & C. $17 \%$ \\
\hline & D. Group discussion & D. $3 \%$ \\
\hline \multirow{4}{*}{$\begin{array}{l}\text { 3. What was the approach that } \\
\text { your instructor applied for } \\
\text { writing evaluation? }\end{array}$} & A. Juku online evaluation system & A. $70 \%$ \\
\hline & B. Instructor feedback and group discussion & B. $13 \%$ \\
\hline & C. Juku online system and instructor's feedback & C. $12 \%$ \\
\hline & D. Instructor's individual feedback & D. $5 \%$ \\
\hline \multirow{4}{*}{$\begin{array}{l}\text { 4. What was the most effective } \\
\text { evaluation approach? }\end{array}$} & A. Instructor's individual feedback & A. $38 \%$ \\
\hline & B. Class discussion & B. $29 \%$ \\
\hline & C. Juku online evaluation system & C. $25 \%$ \\
\hline & D. Group discussion & D. $8 \%$ \\
\hline
\end{tabular}


TABLE 4

Participants' Satisfaction With Traditional Writing Instruction (Question 5-7)

\begin{tabular}{lccccc}
\hline \multicolumn{1}{c}{$\begin{array}{c}\text { Response Option } \\
\text { Question }\end{array}$} & A & B & C & D & E \\
\hline 5. My engagement was increased. & $26 \%$ & $27 \%$ & $7 \%$ & $13 \%$ & $27 \%$ \\
6. I could benefit from the writing instruction. & $18 \%$ & $43 \%$ & $16 \%$ & $8 \%$ & $15 \%$ \\
7. I used the writing strategies I learned. & $13 \%$ & $51 \%$ & $11 \%$ & $14 \%$ & $11 \%$ \\
\hline
\end{tabular}

Note. $\mathrm{A}=$ Mostly agree $\mathrm{B}=$ Somewhat agree $\mathrm{C}=$ Uncertain $\mathrm{D}=$ Somewhat disagree $\mathrm{E}=$ Mostly disagree

Furthermore, as mentioned previously, only $52 \%$ of the students indicated that they revised their essays after receiving instructors' evaluations, the implication being that that no matter what kind of evaluation was given, when no further revision or follow-up evaluation was available, neither of the evaluation approaches played a positive role in improving students' writing skills or forming good writing habits. Briefly, the results of this section seem to imply that students played passive roles in the process of writing evaluation and were accustomed to relying on curricular instruction and instructor feedback. In sum, writing was regarded as a one-time activity, with scant regard for the importance of different stages in the whole writing process or positive engagement by students.

\section{The Effect of Juku Online Writing System as an Interactive Writing Tool as Incorporated Into a Process-Genre Approach}

After 12 weeks' interactive writing instruction and practice, students' satisfaction with the process-genre approach as well as their pretest and post-test performance were analyzed.

\section{1) Participants' Satisfaction With the Writing Approach}

The survey for this section of students was divided into two parts. The first part explored students' satisfaction with instruction overall, while the second part focused specifically on the Juku online system.

The results for the first part of the survey (see Table 5) showed that the percentage of students who somewhat or mostly agreed that they were more interested in writing increased $21 \%$, from $45 \%$ to $66 \%$, from before to after implementation of reform measures. Similarly, the percentage of students who somewhat or mostly agreed that they were more self-confident in writing increased from 15\%, from 59\% to 74\%. Results for students' writing habits also indicated that more students modified and revised their essays repeatedly according to feedback from multiple evaluations, a $14 \%$ increase from $54 \%$ to $68 \%$. Meanwhile, most students agreed that they benefited from both peer evaluation and teacher evaluation as well.

TABLE 5

Participants' Satisfaction With Instruction Overall (Question 1-8)

\begin{tabular}{|c|c|c|c|c|c|c|}
\hline \multirow{2}{*}{ Content } & \multirow{2}{*}{$\begin{array}{l}\text { Response Option } \\
\text { Question }\end{array}$} & \multirow[b]{2}{*}{ A } & \multicolumn{4}{|c|}{ Percentage $(N=77)$} \\
\hline & & & $\mathrm{B}$ & $\mathrm{C}$ & $\mathrm{D}$ & $\mathrm{E}$ \\
\hline \multirow{2}{*}{$\begin{array}{l}\text { Writing } \\
\text { attitudes }\end{array}$} & 1. I was interested in writing. & $20 \%$ & $46 \%$ & $5 \%$ & $19 \%$ & $10 \%$ \\
\hline & 2. I was confident in writing. & $31 \%$ & $43 \%$ & $6 \%$ & $14 \%$ & $6 \%$ \\
\hline \multirow{2}{*}{ Writing habits } & 3. I revised my essay repeatedly. & $38 \%$ & $30 \%$ & $7 \%$ & $16 \%$ & $9 \%$ \\
\hline & 4. I used the strategies I learned. & $37 \%$ & $49 \%$ & $5 \%$ & $5 \%$ & $4 \%$ \\
\hline \multirow{4}{*}{$\begin{array}{l}\text { Interaction } \\
\text { and } \\
\text { engagement }\end{array}$} & 5. My engagement was increased. & $57 \%$ & $27 \%$ & $5 \%$ & $6 \%$ & $5 \%$ \\
\hline & 6. I benefited from the instruction. & $39 \%$ & $50 \%$ & $5 \%$ & $3 \%$ & $3 \%$ \\
\hline & 7. I benefited from peer evaluation. & $31 \%$ & $46 \%$ & $5 \%$ & $10 \%$ & $8 \%$ \\
\hline & 8. I benefited from the instructor's evaluation. & $59 \%$ & $31 \%$ & $3 \%$ & $3 \%$ & $4 \%$ \\
\hline
\end{tabular}

Note. $\mathrm{A}=$ Mostly agree $\mathrm{B}=$ Somewhat agree $\mathrm{C}=$ Uncertain $\mathrm{D}=$ Somewhat disagree $\mathrm{E}=$ Mostly disagree

However, since this evaluation system focused mainly on language expressions, the study used the combination of a collective discussion and individual feedback in teaching, and conducted comprehensive guidance and evaluation of students' writing ability in writing methods and discourse structure. The effect of this writing approach 
was positive, with $86 \%$ of the students indicating they consciously made use of the writing strategies they learned in class, a $22 \%$ increase from $64 \%$ to $86 \%$ following the instructional reform. Due to the instructor's greater emphasis on arousing students' engagement throughout the process of writing, students were more positive about their writing, revising, and provision of peer-feedback. The percentage of students who somewhat or mostly agreed that they benefited from the writing instruction increased $28 \%$, from $61 \%$ to $89 \%$. The percentage of students who somewhat or mostly agreed that they benefited from both peer evaluation and their instructors' evaluation attained $77 \%$ and $90 \%$ respectively.

The results of the second part of the survey (see Table $6 \& 7$ ) indicated that under instructors' active guidance, the Juku system exhibited the intended advantages of timely, fast and concrete evaluation and played a positive role in improving students' attitudes and good writing habits. The percentage of student who somewhat or mostly agreed that they were in favor of and benefited from this system increased by $25 \%$ and $26 \%$, from $59 \%$ to $84 \%$ and $63 \%$ to $89 \%$, respectively. The percentage of students who somewhat or mostly agreed that the biggest advantage of this system over the traditional one was its timely feedback was much higher than for other dimensions. The advantage of timely feedback was also reflected in responses to the item concerning the aspects that still needed to be improved. The two least frequently chosen responses were related to guidance on language expressions and interaction during writing evaluation, indicating students' satisfaction with this system.

In addition, instructors could understand each student's level of knowledge as well as weaknesses, and provide more effective and targeted input. While improving their writing ability, students and teachers generated specific themes, ideas, structures and expressions as well. This helped fill in the gap created by the Juku system's focus on language expressions to a greater extent than on other parts of writing.

TABLE 6

Participants' Satisfaction With Juku System (Question 1-4)

\begin{tabular}{|c|c|c|c|c|c|c|}
\hline \multicolumn{2}{|c|}{ Response Option } & \multicolumn{5}{|c|}{ Percentage $(N=77)$} \\
\hline Content & Question & A & B & $\mathrm{C}$ & $\mathrm{D}$ & $\mathrm{E}$ \\
\hline \multirow{4}{*}{$\begin{array}{l}\text { Effect of Juku } \\
\text { online system }\end{array}$} & 1. I was in favor of Juku. & $22 \%$ & $62 \%$ & $6 \%$ & $6 \%$ & $4 \%$ \\
\hline & 2. I benefited from Juku. & $33 \%$ & $56 \%$ & $2 \%$ & $4 \%$ & $5 \%$ \\
\hline & 3. I revised my essays after Juku. & $60 \%$ & $27 \%$ & $5 \%$ & $4 \%$ & $4 \%$ \\
\hline & 4. Juku online evaluation was fair. & $60 \%$ & $33 \%$ & $2 \%$ & $2 \%$ & $3 \%$ \\
\hline
\end{tabular}

Note. $\mathrm{A}=$ Mostly agree $\mathrm{B}=$ Somewhat agree $\mathrm{C}=$ Uncertain $\mathrm{D}=$ Somewhat disagree $\mathrm{E}=$ Mostly disagree

TABLE 7

Participants' Satisfaction With Juku System (Question 5-7)

\begin{tabular}{|c|c|c|}
\hline Question & Response Option & Percentage $(N=77)$ \\
\hline \multirow{4}{*}{$\begin{array}{l}\text { 5. What was the biggest improvement } \\
\text { you made after using the Juku online } \\
\text { system? }\end{array}$} & A. Language expressions & A. $44 \%$ \\
\hline & B. Ideological contents & B. $22 \%$ \\
\hline & C. Layouts & C. $18 \%$ \\
\hline & D. Logical coherence & D. $16 \%$ \\
\hline \multirow{4}{*}{$\begin{array}{l}\text { 6. What was the biggest advantage of the } \\
\text { Juku online evaluation? }\end{array}$} & A. Timely marking & A. $33 \%$ \\
\hline & B. Feedback on language expressions & B. $26 \%$ \\
\hline & C. Knowledge extension & C. $24 \%$ \\
\hline & D. Rich online practice & D. $17 \%$ \\
\hline \multirow{4}{*}{$\begin{array}{l}\text { 7. Which aspect should be improved in } \\
\text { the Juku online system? }\end{array}$} & A. Guidance on writing methods & A. $34 \%$ \\
\hline & B. Evaluation on the layouts & B. $28 \%$ \\
\hline & C. Interaction on writing evaluation & C. $27 \%$ \\
\hline & D. Guidance on language expressions & D. $11 \%$ \\
\hline
\end{tabular}

\section{2) Participants' Improvement in Writing Ability}

Improvement in writing ability was measured by examining participants' writing scores as well as indicators of lexical variables, syntactic variables and discourse variables. The scores for the lexical and syntactic levels were measured by the Juku online autonomous marking system based on corpus analysis, which has been shown to be valid and reliable. Students' performance at the discourse level was evaluated by three instructors according to the marking standard of national CET 4 paper-writing. The results of students' writing scores during 12 weeks' writing 
practice indicated that writing instruction could play a positive role in the improvement of language expressions as well as discourse ability (see Table 8).

Numerous significant differences were found between students' mean scores at pre-test (beginning of 12 week period) and post-test (end of 12 week period). Briefly, students' mean scores overall at post-test were significantly higher than at pre-test, increasing from 79.3 to 83.9 points and indicating a positive effect of process-genre writing instruction $(p<.05)$. Similarly, significant improvement was observed with respect to the levels of both lexical variables and syntactic variables concerning vocabulary abundance and sentence accuracy $(M=5.63 \& 5.86 ; .91$ $\& .98$ respectively; $p=.005 \& .002)$. Average length of words and sentences also increased significantly $(M=4.55$ $\& 4.88 ; 16.32 \& 20.50$ respectively; $p=.000 \& .001$ ), perhaps reflecting greater self-confidence and willingness to express ideas in more complex language expressions. Furthermore, significantly more students were willing to use subordinate clauses in writing $(M=13.22 \& 15.92$ respectively; $p=.002)$, which also implied that students became more self-confident in writing. However, no significant difference was found for spelling accuracy $(M=.99 \& .99$ respectively; $p=.124)$.

As for students' improvements at the discourse level, the results were consistent with those of the self-assessment surveys. Significant improvements in ideological content and layout were observed $(M=.92 \& .96 ; .91 \& .98$ respectively; $p=.005 \& .002$ ), which likely reflected the effects of interactive instruction especially with respect to peer discussion, peer evaluation and instructor evaluation. However, no significant differences were found for coherence $(M=.77 \& .78$ respectively; $p=.102)$, which implies a specific challenge for discourse-level improvement.

TABLE 8

Paired-Sample T-Tests on Participants' Writing Improvement Factors

\begin{tabular}{|c|c|c|c|c|c|}
\hline Variable & Test & $N$ & $M$ & $S D$ & Sig.* \\
\hline \multirow{2}{*}{ 1. Vocabulary abundance } & Pre & 77 & 5.63 & .54 & \multirow{2}{*}{$.005 *$} \\
\hline & Post & 77 & 5.86 & .80 & \\
\hline \multirow{2}{*}{ 2. Average length of words } & Pre & 77 & 4.55 & .23 & \multirow{2}{*}{$.000 *$} \\
\hline & Post & 77 & 4.88 & .37 & \\
\hline \multirow{2}{*}{ 3. Spelling accuracy } & Pre & 77 & .98 & .01 & \multirow{2}{*}{.124} \\
\hline & Post & 77 & .99 & .02 & \\
\hline \multirow{2}{*}{ 4. Average length of sentences } & Pre & 77 & 16.32 & 4.39 & \multirow{2}{*}{$.001^{*}$} \\
\hline & Post & 77 & 20.50 & 10.2 & \\
\hline \multirow{2}{*}{ 5. Total number of subordinate clauses } & Pre & 77 & 13.22 & 4.64 & \multirow{2}{*}{$.002 *$} \\
\hline & Post & 77 & 15.92 & 7.39 & \\
\hline \multirow{2}{*}{ 6. Sentence accuracy } & Pre & 77 & .91 & .01 & \multirow{2}{*}{$.002 *$} \\
\hline & Post & 77 & .98 & .06 & \\
\hline \multirow{2}{*}{ 7. Ideological contents } & Pre & 77 & .92 & .01 & \multirow{2}{*}{$.005^{*}$} \\
\hline & Post & 77 & .96 & .05 & \\
\hline \multirow{2}{*}{ 8. Layouts } & Pre & 77 & .91 & .01 & \multirow{2}{*}{$.002 *$} \\
\hline & Post & 77 & .98 & .06 & \\
\hline \multirow{2}{*}{ 9. Logical coherence } & Pre & 77 & .77 & .01 & \multirow{2}{*}{.102} \\
\hline & Post & 77 & .78 & .02 & \\
\hline \multirow{2}{*}{ 10. Scores } & Pre & 77 & 79.3 & 6.27 & \multirow{2}{*}{$.000 *$} \\
\hline & Post & 77 & 83.9 & 6.42 & \\
\hline
\end{tabular}

Note. ${ }^{*} p$-values considered significant at the 0.05 level $(p<.05)$.

In sum, improvement with respect to lexical variables, syntactic variables and discourse variables could be seen among students who used the Juku system as part of a process-genre approach to writing instruction. Compared to the traditional approach, the process-genre approach improved students' writing ability. It increased their enthusiasm for learning and self-confidence in writing, and helped them develop good writing habits as well.

\section{CONCLUSION}

In order to improve students' writing ability, the present study explored why and how to use the Juku online writing evaluation system as an interactive tool as part of a process-genre approach to teaching writing to college students in 
an ethnic minority area of China. First, the disadvantages of the traditional approach to writing instruction were analyzed. Survey data confirmed that traditional writing instruction is still exam-teacher-centered, which places high value on results instead of process. The lack of interaction among teachers and students in traditional approaches makes it difficult to either engage students' interest and participation in the writing process or to improve their writing ability in the long term. Based on survey data and writing practice results, the present study demonstrated the positive effects of a process-genre approach to writing instruction that incorporated the Juku interactive writing system. Benefits included improved quality of writing, development of good writing habits, and affective variables such as enthusiasm for learning writing.

The findings of the present study suggest that while conducting interactive writing instruction, instructors should promote positive attitudes, student interest, and student self-confidence in writing. Only if these emotional factors are encouraged can students' overall writing ability be improved. This study indicates that students are more willing to modify their writing with the feedback offered by the Juku online writing evaluation system, and more conscious about using the writing strategies they learned. Furthermore, students are more willing to try and use more advanced vocabulary and subordinate clauses, and to enrich their language expressions due to their positive engagement.

Survey data concerning students' views on traditional writing instruction also indicate that traditional teacherproduct-centered instruction alone is not sufficient to improve students' writing ability. Rather, instructors should carry out student-centered instruction in teaching practice, help improve students' creative thinking, and encourage language output through interactive and contextual teaching practice. Due to students' weakness at the discourse level and cultural complexities in ethnic minority areas, instructors should pay more attention to cultural differences and cross-cultural communication in writing topics and discourse selection, promoting students' understanding, and integrating English culture with their own culture and others. In this way, writing instruction can be a means of contextual ideological expression and a meaningful form of cross-cultural communication

Furthermore, the findings suggest that both instructors and students should place a high value on the writing process instead of the results of writing alone. Through a process-genre approach, the advantages of the Juku online writing evaluation system can be utilized. This system offers an open, interactive platform for instructors and students to be involved in the writing process, including determining the theme, layout and content, as well as providing instructor and peer feedback. This highly interactive communication can help students form good writing habits and improve their language expressions and discourse ability as well.

In addition, evaluation should be regarded as a crucial part of the entire writing process instead of the final step of instruction. The Juku online writing evaluation system makes multiple interactive evaluations possible. The biggest advantage of this online evaluation system lies in its timely and comprehensive feedback on language use at lexical, grammatical and syntactic levels. With the instructor's guidance and motivation, students are willing to make use of opportunities to revise and modify their writings repeatedly. The system's constant and detailed feedback, and suggestions on language expressions and extended online practice stimulate and benefit students as well. As for discourse structure, ideological content, and logical coherence, both instructor feedback and peer evaluation can play positive roles, and complement the online evaluation system. In this way, the effectiveness and efficiency of the overall approach to evaluation can be improved.

To sum up, this study indicates that use of the Juku online writing evaluation system as an interactive writing tool within a process-genre approach to instruction can improve the effectiveness and efficiency of writing instruction through creative use of an existing network of teaching and evaluation resources. The findings of this study are limited of course by the restriction of the sample to one university in China. Another limitation is the relatively short period of writing practice (12 weeks) which makes it difficult to know about effectiveness over longer periods of time. Longer period classroom observation and writing practice in different regions of China would contribute to a better understanding and promotion of college English writing practice.

\section{REFERENCES}

Badger, R., \& White, G. (2000). A process-genre approach to teaching writing. ELT Journal, 54(2), 153-160. https://doi.org/10.1093/elt/54.2.153 
Cai, Y. N. (2009). An experimental study of the effect of application of cooperative learning theory on process-genre writing approach in college English (Unpublished master's thesis). Liaoning Normal University, China. Retrieved from https://kns.cnki.net/kcms/detail/detail.aspx?FileName=2010024988.nh\&DbName=CMFD2010

Cheng, X. T., \& Zhao, S. Q. (2016). On students' key competences in English as a foreign language curriculum. Teaching Material and Method, 36(5), 79-86. https://doi.org/10.19877/j.cnki.kcjcjf.2016.05.012

Chinese Ministry of Education. (2017). General English curriculum standards in China. Beijing: Beijing Normal University Publishing Group.

Gu, C. H., \& Wang, L. (2012). An empirical study on college English writing teaching based on Juku correcting network. Journal of Yangzhou University (Higher Educational Study Edition), 16(4), 92-96. https://doi.org/10.19411/j.cnki.1007-8606.2012.04.021

Han, J. L. (2001). English writing teaching: A process-genre approach. Foreign Language, 4, 35-40. Retrieved from https://kns.cnki.net $/ \mathrm{kcms} /$ detail/detail.aspx?FileName $=$ WYJY200104006 $\&$ DbName $=$ CJFQ2001

Jiao, S. H., \& Yuan, W. J. (2016). Research and practice on flipped classroom for higher vocational English writing based on Juku correcting network. Journal of Wuhan Polytechnic, 15(4), 76-78+88. Retrieved from https://kns.cnki.net/kcms/detail/detail.aspx?FileName=WHZB201604018\&DbName=CJFQ2016

Kim, S. Y. (2016). The impact of explicit writing instruction based on process-genre approach on high school students' writing. Studies in English Education, 21(4), 1-33. http://doi.org/10.22275/SEE.21.4.01

Lee, S. J. (2010). An educational reexamination of formalism writing theory. Writing Studies, 11, 167-199.

Li, F. P. (2015). A study on dynamic teaching mode in college English writing based on process approach. Journal of Higher Education, 15, 52-53. Retrieved from https://kns.cnki.net/kcms/detail/detail.aspx?FileName= GJXK201515027\&DbName=CJFQ2015

Liu, D. P. (2018). A survey study on secondary school students' key competences in English in China. The Asian EFL Journal, 20(12), 108-130. Retrieved from https://www.asian-efl-journal.com/main-editions-new/volume-20issue-12-2-december-2018-quarterly-journal/

Liu, D. P. (2019). Student and teacher attitudes about competence-based instruction in secondary English classes in China. International Journal of Education and Social Science, 6(2), 28-34. Retrieved from http://www.Ijessnet.com/current.html?volume=109

Ministry of Education. (2020). College English teaching guidelines. Shanghai: Shanghai Foreign Language Education Press.

Shi, F. F. (2015). A study on application of the process-genre approach in teaching of college English writing (Unpublished master's thesis). Jilin University, Changchun, China. Retrieved from https://kns.cnki.net/kcms/ detail/detail.aspx?FileName $=1015595475$. nh $\&$ DbName $=$ CMFD2015

Wang, M. Y. (2019). A study on the effect of process-genre approach on college English writing self-efficacy (Unpublished master's thesis). Shanxi Normal University, Xian, China. Retrieved from https://kns.cnki.net/ $\mathrm{kcms} /$ detail/detail.asp $x$ ?FileName $=1019223813$. nh $\&$ DbName $=$ CMFD2020

Wu, L. L. (2005). The differences of writing strategies employed by GLL and ULL of college non-English majors. Journal of Hunan University (Social Sciences), 19(3), 96-100. Retrieved from https://kns.cnki.net/kcms/ detail/detail.aspx?FileName $=$ HDXB20050301D\&DbName=CJFQ2005

$\mathrm{Xu}, \mathrm{F}$. (2012). Teaching and researching English writing. Beijing: Foreign Language Teaching and Research Press.

Yang, H. J. (2015). Study on university students' writing education through critical essay writing. The Journal of Literary Creative Writing, 14(1), 135-169.

Yang, S. X. (2002). A study on the use of writing strategies by successful and unsuccessful writers. Foreign Language World, 3, 57-64. Retrieved from https://kns.cnki.net/kcms/detail/detail.aspx?FileName=WYJY200203010 $\& \mathrm{DbName}=\mathrm{CJFQ} 2002$

Yao, X. H. (2010). The impact of the product-approach and process-genre approach on students' writing strategies and writing competence. Foreign Languages and Their Teaching, 252(3), 30-34. https://doi.org/10.13458/j.cnki.flatt.000228

Yu, F., \& Zhang, H. F. (1996). A study on product-based approach, process-based approach and content-based approach in writing teaching. Foreign Languages, 3, 38-40. Retrieved from https://kns.cnki.net/kcms/detail/detail.aspx?FileName $=$ WYJY603.010\&DbName=CJFQ1996 
Zhang, S. (2013). An application study on process-genre approach in teaching English writing for non-English majors (Unpublished master's thesis). Bohai University, Jinzhou, China. Retrieved from https://kns.cnki.net/ $\mathrm{kcms} /$ detail/detail.aspx?FileName=1013192237.nh\&DbName=CMFD2013

Zhang, X. F. (2009). Promote the teaching of writing in college English with lexical chunk-centered method. Journal of Yangzhou University (Higher Education Study Edition), 13(3), 90-92. https://doi.org/10.19411/j.cnki.10078606.2009.03.026

\section{APPENDIX 1}

The Whole Class Overview Interface

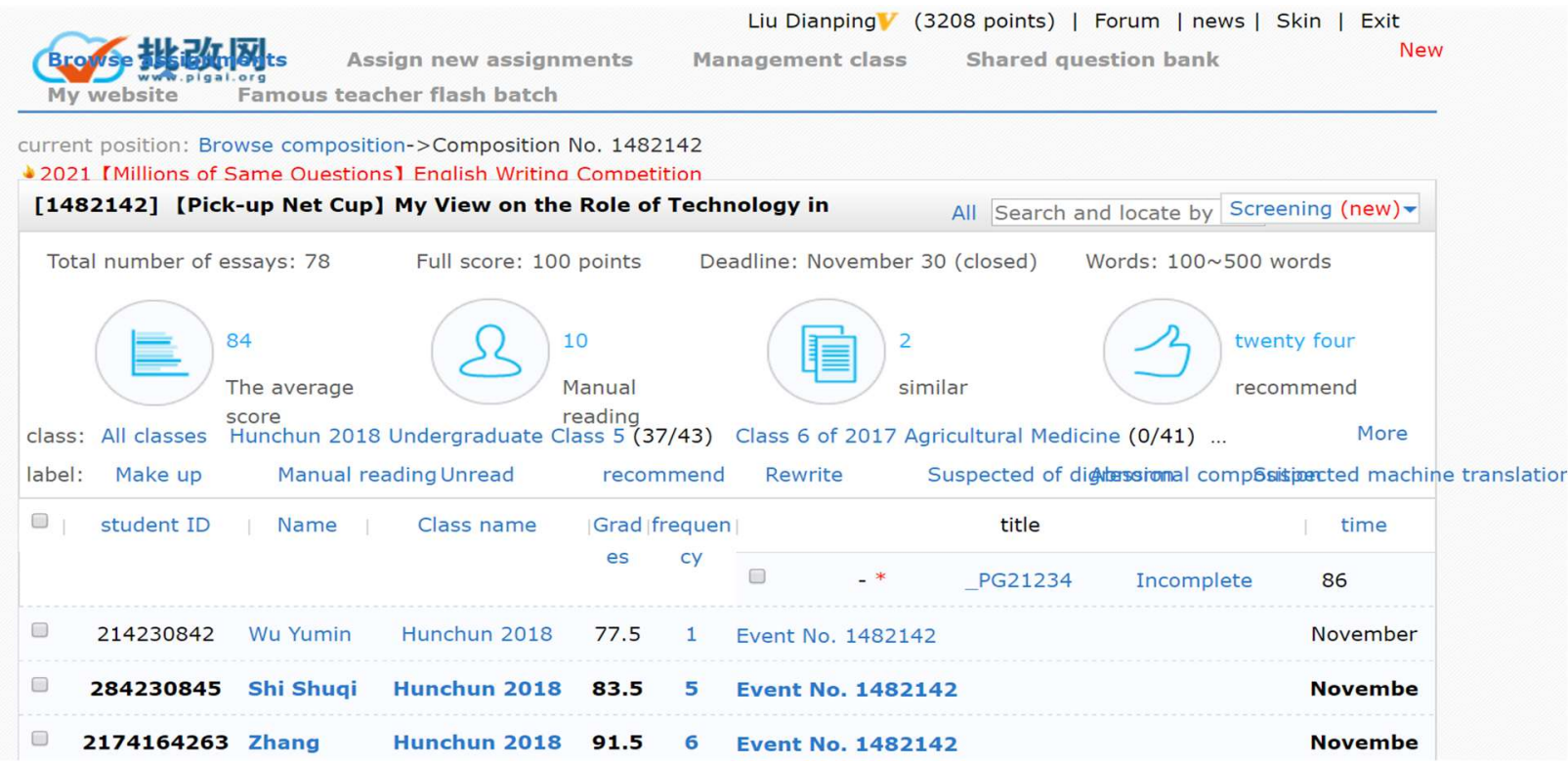

\section{APPENDIX 2}

Two Essays Vocabulary Difficulty Comparison Interface

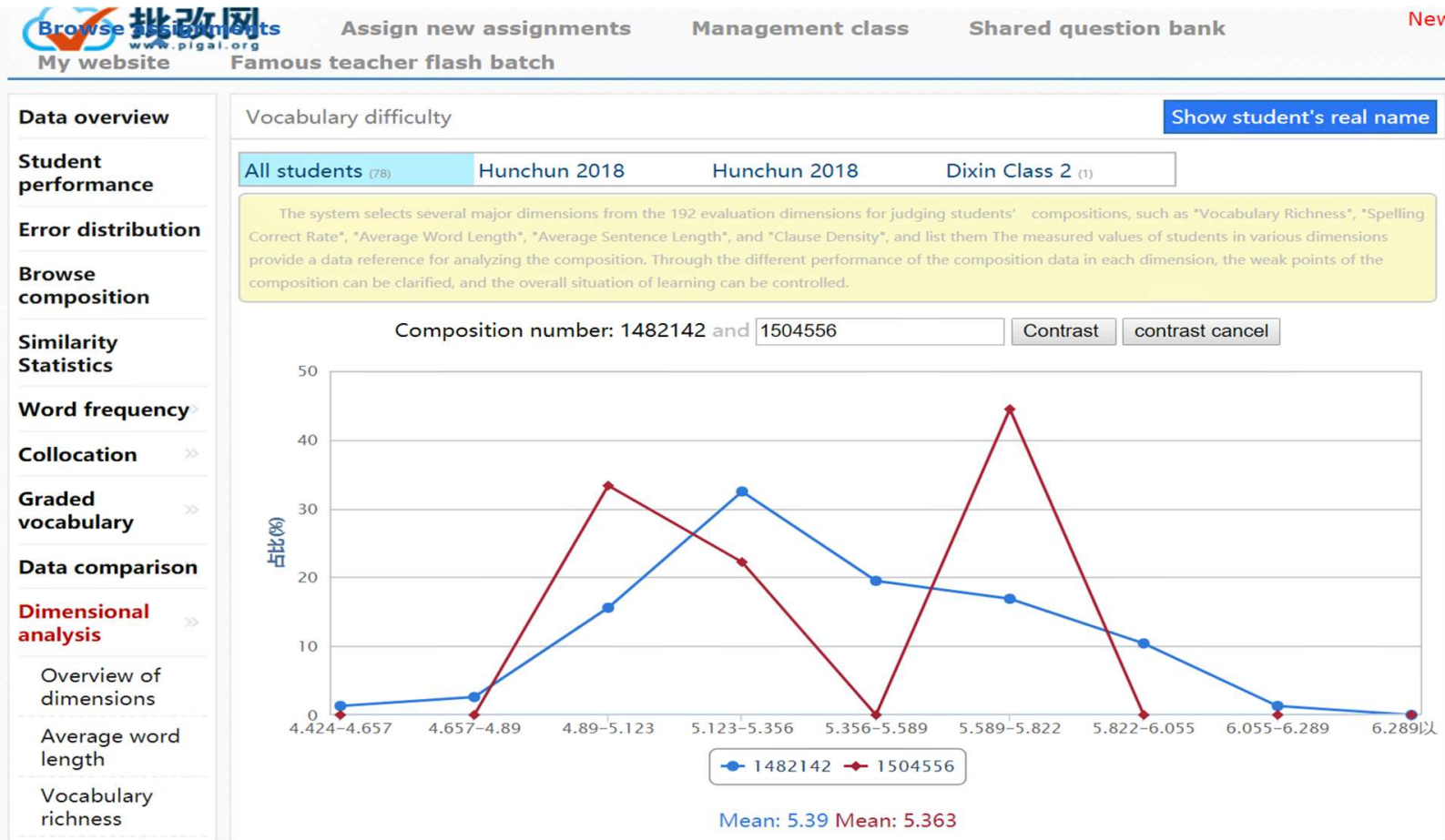




\section{APPENDIX 3}

The Whole Class Data Overview Interface

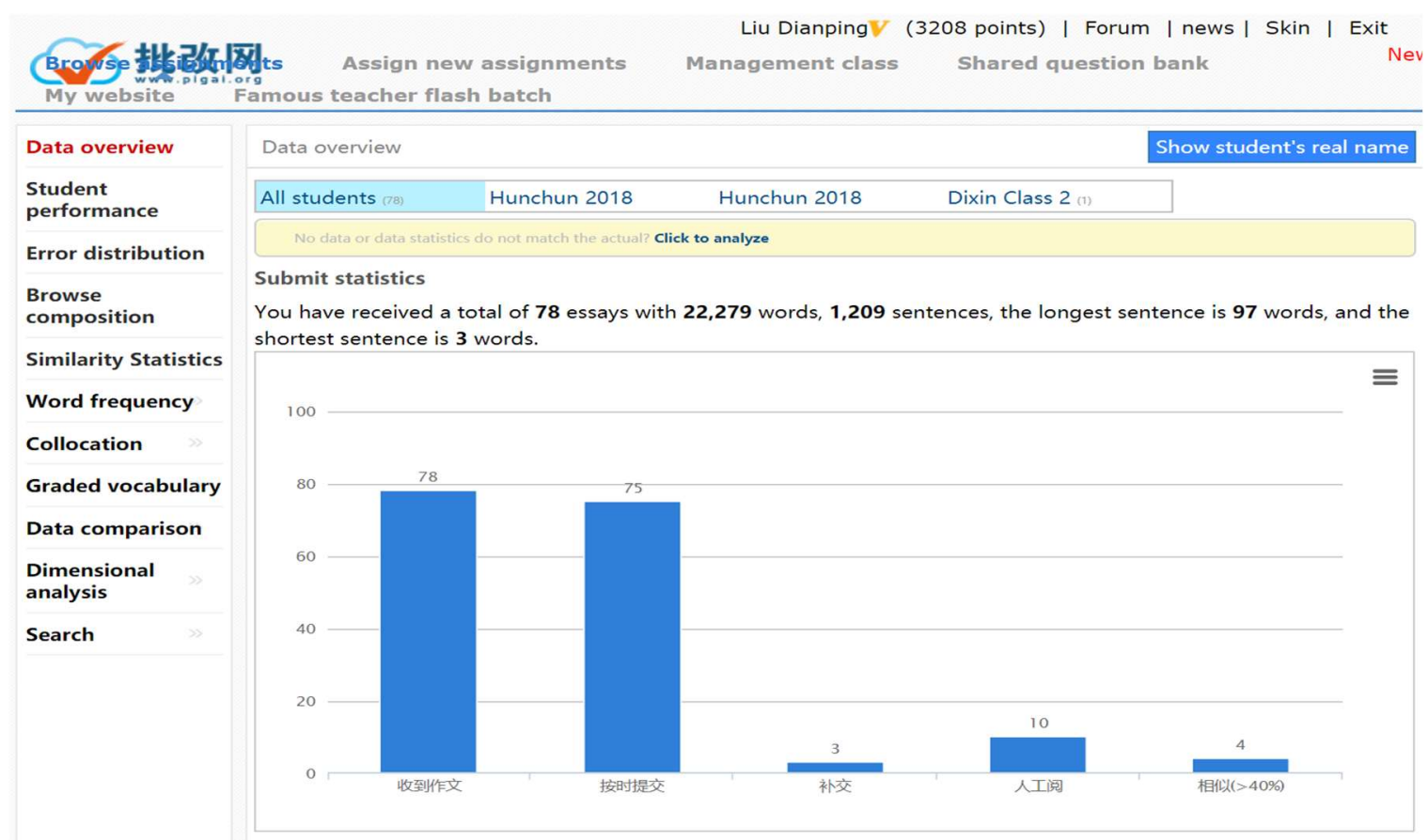

Score distribution

The highest score for student composition is 91.4 (? classmate), and the lowest score is 23.1 (? classmate). Average score: $\mathbf{7 7 . 1}$ points.

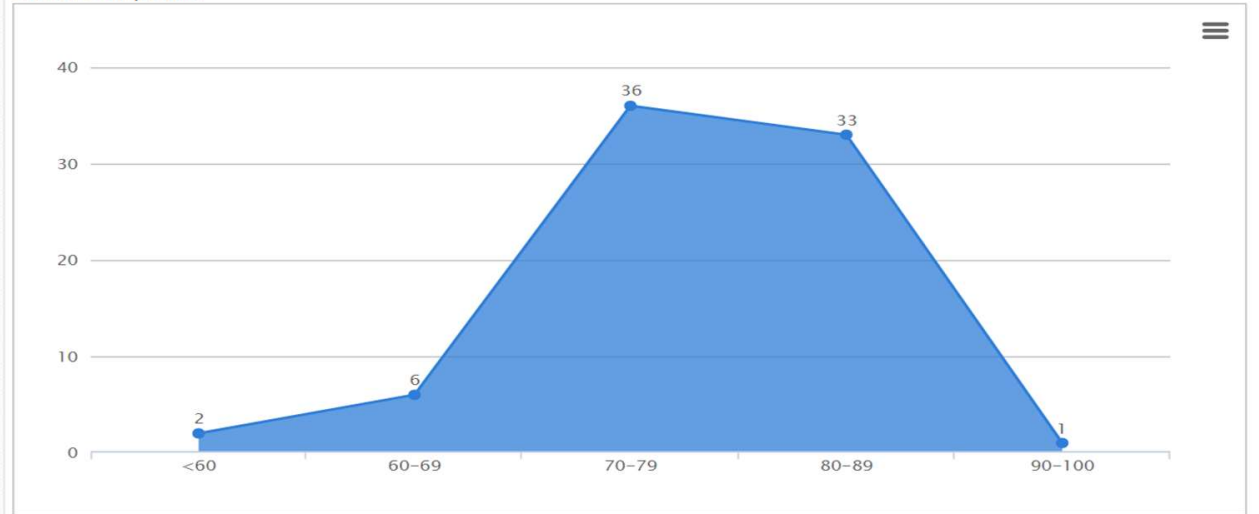

Error statistics

The system found a total of $\mathbf{8 6 0}$ errors in the students' composition. Among them, misspelling errors with the wrong case verb agreement error of the sentence article error for the students most commonly committed.

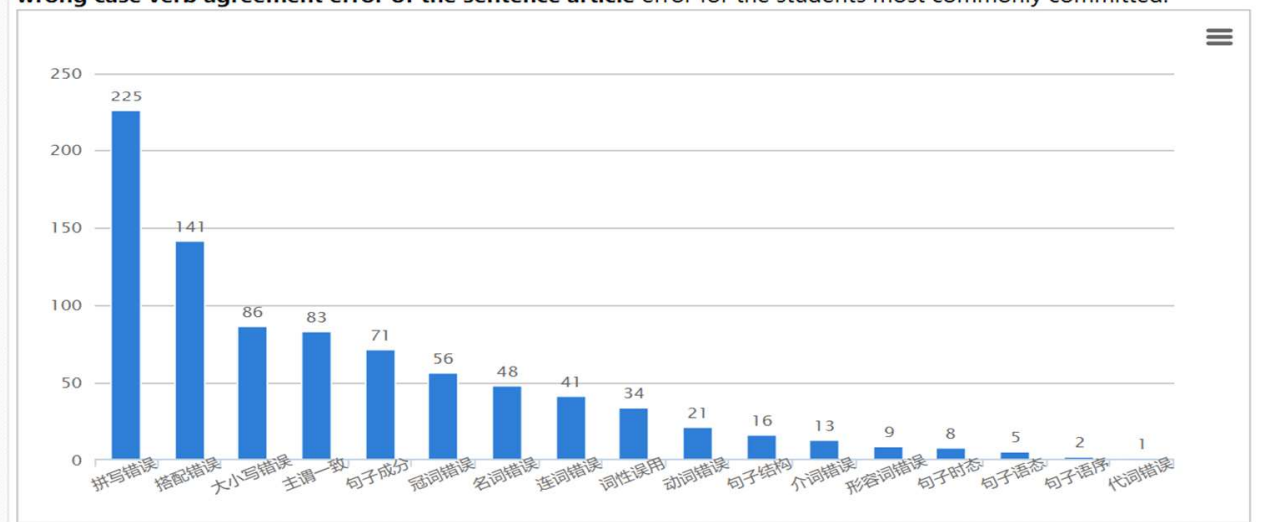

Note. Appendix 1 is based on part of the original screenshot due to its inconvenient length and our practical need. 